\title{
Reflections About the Gut, A Microbiologist's Perspective
}

\author{
Bernard AM Van der Zeijst* \\ Department of Medical Microbiology, Leiden University Medical Center, The Netherlands
}

Received: 阱 August 06, 2018; Published: 觜 August 09, 2018

*Corresponding author: Bernard AM Van der Zeijst, Department of Medical Microbiology, Leiden University Medical Center, The Netherlands

\section{Opinion}

Without doubt, the original function of the human gut was to digest and absorb food. Its epithelial cells absorb food after it has been processed to smaller components by enzymatic digestion. Comparable epithelial processes are also found in animals, including sea animals, and plants [1]. Disturbance of the gut homeostasis by infections leads to disease. From mild diarrhea of short duration (e.g. caused by poliovirus, rotavirus, norovirus and Campylobacter) to lethal infections by toxin producing bacteria such as cholera. Cholera often occurs as a result of crowding and poor hygiene. It was very problematic during the first industrial revolution in the UK where poor migrants lived under dismal conditions. This situation was a trigger for Karl Marx and Friedich Engels to write the Communist Manifesto. More recently it hit Haiti after the earthquake in 2010. In addition to acute and life threating disease an accumulation of milder diarrheal episodes can have dire consequences. It may cause under nutrition with as results impaired development of the brain. An analysis by Eppig et al. [2] found an inverse correlation between disease burden and average intelligence. They explain this by a lack of energy to build the brain, as a consequence of infectious disease [2]. Another, Brazilian, study found a correlation between early childhood diarrhea and impaired growth and cognitive abilities [3].

I used to teach my students that they have much more bacteria in their gut (about $4.10^{13}$ ) than cells in their brain $\left(10^{11}\right.$ ) [4]. But for many years I had to add that most of these bacteria could not be cultured and that their function was largely unknown. That has completely changed. The gut microbiota, the present name for all bacteria in the gut, is now know to have important metabolic, hormonal and immunologic functions and exchange signals with the body, even with the brain.

a. The impact of gut microbiota on obesity has become a distinct research field in the last ten years, helped by the urgency to slow down the large increase in numbers of (morbid) obese people. Early data pointed at the ratio between bacteria of the phyla Bacteroidetes and Firmicutes as a correlate for obesity. This was underpinned by experiments manipulating this ratio [5]. Later data have confirmed the relationship between obesity and the gut microbiota, but more research is needed for complete understanding $[6,7]$.

b. The gut microbiota acts as an endocrine organ by producing precursors to hormones but also directly releases several neurotransmitters that directly interact with the brain [7].

c. During the last three years it has become clear that intestinal microbiota modulates cancer immunotherapy. Checkpoint inhibitors, a class a of antibodies, are able to unleash a person's immune system against tumor cells, but only $20-40 \%$ of people respond to treatment. This seems, at least partially, determined by the composition of the intestinal microbiota [8].

Not everybody will call gut microbiota her/his second brain [9], but the insights about the many effects it has will certainly cause a shift in gastroenterology from the treatment of disease to prevention [10].

\section{References}

1. Foster KR, Schluter J, Coyte KZ, Rakoff Nahoum S (2017) The evolution of the host microbiome as an ecosystem on a leash. Nature 548(7665): 43-51.

2. Eppig C, Fincher CL, Thornhill R (2010) Parasite prevalence and the worldwide distribution of cognitive ability. Proc Biol Sci 277(1701): 3801-3808.

3. Pinkerton R, Oria RB, Lima AA, Rogawski ET, Oria MO, et al. (2016) Early Childhood Diarrhea Predicts Cognitive Delays in Later Childhood Independently of Malnutrition. Am J Trop Med Hyg 95(5): 1004-1010.

4. Sender R, Fuchs S, Milo R (2016) Revised Estimates for the Number of Human and Bacteria Cells in the Body. PLoS Biol 14(8): e1002533.

5. Clarke SF, Murphy EF, Nilaweera K, Ross PR, Shanahan F, et al. (2012) The gut microbiota and its relationship to diet and obesity: new insights. Gut Microbes 3(3): 186-202.

6. Tseng $\mathrm{CH}, \mathrm{Wu} \mathrm{CY}$ (2018) The gut microbiome in obesity. J Formos Med Assoc pii: S0929-6646(18): 30437-30446. 
7. Clarke G, Stilling RM, Kennedy PJ, Stanton C, Cryan JF, et al. (2014) Minireview: Gut microbiota: the neglected endocrine organ. Mo Endocrinol 28(8): 1221-1238.

8. Guglielmi G (2018) How gut microbes are joining the fight against cancer. Nature 557(7706): 482-484.
BY Commons Attribution 4.0 License

To Submit Your Article Click Here:

Submit Article

DOI: $10.32474 /$ CTGH.2018.01.000110
9. Ridaura V, Belkaid Y (2015) Gut microbiota: the link to your second brain. Cell 161(2): 193-194.

10. Panduro A, Rivera-Iniguez I, Sepulveda Villegas M, Roman S (2017) Genes, emotions and gut microbiota: The next frontier for the gastroenterologist. World J Gastroenterol 23(17): 3030-3042.

$\begin{array}{r}\text { Current Trends in Gastroenterology } \\ \text { and Hepatology }\end{array}$
Assets of Publishing with us
- Global archiving of articles
- Immediate, unrestricted online access
- Rigorous Peer Review Process
- Authors Retain Copyrights
- Unique DOI for all articles

